\title{
Article/Artigo
}

\section{Methicillin-resistant Staphylococcus aureus bloodstream infection: risk factors and clinical outcome in non-intensive-care units}

\author{
Infecção de corrente sanguínea por Staphylococcus aureus resistente à meticilina: \\ fatores de risco e evolução clínica em unidades não críticas
}

Karinne Spirandelli Carvalho Naves ${ }^{1}$, Natália Vaz da Trindade ${ }^{1}$ and Paulo Pinto Gontijo Filho ${ }^{1}$

\begin{abstract}
Introduction: Methicillin-resistant Staphylococcus aureus (MRSA) is spread out in hospitals across different regions of the world and is regarded as the major agent of nosocomial infections, causing infections such as skin and soft tissue pneumonia and sepsis. The aim of this study was to identify risk factors for methicillin-resistance in Staphylococcus aureus bloodstream infection (BSI) and the predictive factors for death. Methods: A retrospective cohort of fifty-one patients presenting bacteraemia due to S. aureus between September 2006 and September 2008 was analysed. Staphylococcu aureus samples were obtained from blood cultures performed by clinical hospital microbiology laboratory from the Uberlândia Federal University. Methicillinresistance was determined by growth on oxacillin screen agar and antimicrobial susceptibility by means of the disk diffusion method. Results: We found similar numbers of MRSA (56.8\%) and methicillin-susceptible Staphylococcus aureus (MSSA) (43.2\%) infections, and the overall hospital mortality ratio was $47 \%$, predominantly in MRSA group ( $70.8 \%$ vs. $29.2 \%)(\mathrm{p}=0.05)$. Age $(p=0.02)$ was significantly higher in MRSA patients as also was the use of central venous catheter $(p=0.02)$. The use of two or more antimicrobial agents $(p=0.03)$ and the length of hospital stay prior to bacteraemia superior to seven days $(p=0.006)$ were associated with mortality. High odds ratio value was observed in cardiopathy as comorbidity. Conclusions: Despite several risk factors associated with MRSA and MSSA infection, the use of two or more antimicrobial agents was the unique independent variable associated with mortality.
\end{abstract}

Keywords: Staphylococcus aureus. MRSA. Bacteraemia. Risk factors.

\section{RESUMO}

Introdução: Methicillin-resistant Staphylococcus aureus (MRSA), se disseminou nos hospitais em diferentes regiões do globo, e é atualmente o principal agente de infecções hospitalares causando infecções de pele, tecidos moles, pneumonia e sepse. O objetivo deste estudo foi identificar fatores de risco para resistência à meticilina em infecções de corrente sanguínea por Staphylococcus aureus e fatores preditivos de mortalidade. Métodos: Uma coorte de 51 pacientes apresentando bacteremia por S. aureus, entre setembro de 2006 a setembro de 2008 foi analisada. Amostras de S. aureus foram obtidas a partir de hemoculturas realizadas pelo laboratório de microbiologia do hospital de clínicas da Universidade Federal de Uberlândia. A resistência à meticilina foi determinada pelo crescimento no agar triagem para oxacilina e a sensibilidade aos antimicrobianos pelo método de difusão em agar. Resultados: Infecções por MRSA (56,8\%) e methicillin-susceptible Staphylococcus aureus (MSSA) (43,2\%) foram similares e a taxa de mortalidade hospitalar foi de $47 \%$, predominantemente no grupo infectado por MRSA $(70,8 \%$ vs. $29,2 \%)(p=0,05)$. Idade $(p=0,02)$ e a presença de cateter vascular central $(\mathrm{p}=0,02)$ foram significantes no grupo de infectados por MRSA. A evolução demonstrou que o uso de dois ou mais agentes antimicrobianos $(\mathrm{p}=0,03)$ e tempo de internação prévio à bacteremia superior a sete dias $(\mathrm{p}=0,006)$ foram associados à morte. Altos valores de odds ratio foram observados para cardiopatia como comorbidade. Conclusões: Embora vários fatores de risco tenham sido associados a infecções por MRSA e MSSA e mortalidade o uso de dois ou mais agentes antimicrobianos foi a única variável independente para mortalidade. Palavras-chaves: Staphylococcus aureus. MRSA. Bacteremia. Fatores de risco.

1. Programa de Pós-Graduação em Imunologia e Parasitologia Aplicadas, Instituto de Ciências Biomédicas, Universidade Federal de Uberlândia, Uberlândia, MG.

Address to: Dra. Karinne Spirandelli Carvalho Naves. Laboratório de Microbiologia/UFU. Av. Pará 1720, Bl 4C, B. Umuarama, 38405-320 Uberlandia, MG, Brasil.

Phone: 5534 3218-2236; 5534 9681-6907

e-mail: kscnaves@icbim.ufu.br

Received in 13/06/2011

Accepted in 03/08/2011

\section{INTRODUCTION}

A broad variety of infections, ranging from minor infections of the skin to severe infections as bloodstream infections, can be caused by Staphylococcus aureus. Methicillin-resistant Staphylococcus aureus (MRSA) is an endemic nosocomial pathogen, but its geographic spread in the community has been documented ${ }^{1}$. Some previous studies of patients with MRSA bloodstream infection (BSI) have reported higher mortality rates, increased morbidity, and longer hospital length of stay than those with methicillin-susceptible Staphylococcus aureus $\mathrm{BSI}^{2,3}$. In the UK, MRSA infection is cited with increasing frequency as causing or contributing to death ${ }^{4,5}$. Risk factors for methicillin-resistance in these infections have been extensively described, but the studies vary among institutions ${ }^{6,7}$.

Methicillin-resistance among $S$. aureus remains an important problem in Latin America hospitals ${ }^{8}$, but rates vary significantly from hospital to hospital. In Brazil, the Antimicrobial Surveillance Program (SENTRY) ${ }^{9}$ described a prevalence of MRSA bacteraemia of $30.9 \%$ in hospitalized patients between 1997 and 2000, but in large Brazilian teaching hospitals, up to $73 \%$ of clinically significant S. aureus bacteraemia were caused by methicillinresistant strains. Ribas et al. ${ }^{10}$ reported $49.5 \%$ of bloodstream infection in Clinical Hospital of Uberlândia's Federal University due to S. aureus, and recently, Carvalho and Gontijo Filho ${ }^{11}$ described $63.7 \%$ of S. aureus BSI due to MRSA in adult criticalcare unit.

The objectives of this study were to identify institution-specific risk factors for methicillinresistance in S. aureus BSI to determine the predictive factors for death and assess the impact of methicillinresistance on mortality in patients in non-intensivecare units of a Brazilian University Hospital. 


\section{METHODS}

The study was conducted in a 500-bed teaching hospital that provides tertiary care for Uberlândia and surroundings. The investigation was designed as a retrospective cohort of patients presenting bacteraemia due to $S$. aureus. Clinical and epidemiological data were collected from the hospital patient records.

Bloodstream infections were classified as primary when they were not related to any other focus of infection. BSIs were considered to be secondary when they were clinically related to infection in another site than the vascular system ${ }^{12}$. Previous antimicrobial therapy was defined as the use of any antibiotic within 30 days prior to bacteraemia ${ }^{13}$. Antimicrobial therapy was considered to be adequate if the drug used within the first $48 \mathrm{~h}$ after blood culture collection had in vitro activity against the isolated $S$. aureus $\operatorname{strain}^{13}$. Bacteraemiaassociated mortality was characterized by the patient's death during the bacteremic episode and/or 30 days after hospitalization period without any other explanation ${ }^{14}$.

Hemocultures were performed by inoculating $5-10 \mathrm{~mL}$ of blood into a flask of the automatic commercial system Bactec/ Alert ${ }^{\circledR}$ (Vitek system). Positive cultures were further sub-cultured in Müeller-Hinton Agar (Isofar Ltda, Brazil) supplemented with 5\% of human blood and incubated for 24-48h at $35 \pm 2{ }^{\circ} \mathrm{C}$ in the hospital microbiology laboratory. Methicillin-resistance was determined by growth on oxacillin screen agar and antimicrobial suscetibility by means of the disk diffusion method with disks containing antimicrobial agents.

Univariate analysis was used to compare variables for the outcome groups of interest. Continuous variables were compared using Student's $t$ test for normally distributed variables. The $\chi^{2}$ statistic or Fisher's exact test was used to compare categorical variables. Multivariate analysis was performed using multiple logistic regression with stepwise approach for entering new terms into the BioEstat5.0 model with 0.2 as the limit for their acceptance or removal. All $\mathrm{p}$ values lower than 0.2 were considered significant.

\section{Ethical considerations}

The present study was approved by the Ethics Committee of Federal University of Uberlândia (UFU) (014/06).

\section{RESULTS}

Between September 2007 and September 2008, 134 S. aureus BSIs were identified. Methicillin-resistance rate was $59.7 \%(80 / 134)$. Among these cases, 83 were excluded from the study because of incomplete or missing data. A total of 51 episodes in 39 patients were then reviewed. Ten patients presented multiple episodes of MRSA BSI, and two presented multiple episodes of MSSA BSI. Thirty-one infections occurred in male patients, and twenty occurred in female patients (Table 1).

Table 1 shows clinical and demographic characteristics of patients with MRSA and MSSA BSI. Methicillin-resistant Staphylococcus aureus bloodstream infection occurred in older patients, after a longer time following admission when compared with MSSA BSI. All Methicillin-resistant Staphylococcus aureus bloodstream infection were classified as nosocomial. The use of more than two antimicrobial agents, comorbidity, and length of hospital stay prior to bacteraemia longer than seven days were more frequent in MRSA group. Presence of intravascular device was significantly higher in MRSA group than in MSSA group. The sources of S. aureus BSI are also listed in Table 1, and in both, MRSA and MSSA, primary BSIs were the most common sources than secondary ones, and 22 (75.9\%) of whom with MRSA episodes were associated with central venous catheter.

TABLE 1 - Clinical and demographic characteristics of patients with MRSA and MSSA BSIs.

\begin{tabular}{|c|c|c|c|c|}
\hline Characteristics & $\begin{array}{c}\text { MRSA } \\
\mathrm{n}=29(56.8 \%)\end{array}$ & $\begin{array}{c}\text { MSSA } \\
\mathrm{n}=22(43.2 \%)\end{array}$ & Odds ratio $(\mathrm{CI})$ & $\mathrm{p}(\leq \mathbf{0 . 0 5})$ \\
\hline Mortality & $17(58.6)$ & $7(24.1)$ & $3.036(0.949-9.719)$ & 0.057 \\
\hline Age (years), median (range) & $56.13(0-89)$ & $39.6(0-80)$ & & 0.021 \\
\hline Sex (female/male) & $11 / 18$ & $9 / 13$ & $0.882(0.284-2.743)$ & 0.829 \\
\hline LOS before BSI (days), median (range) & $46.4(0-300)$ & $13.7(0-74)$ & & 0.074 \\
\hline \multicolumn{5}{|l|}{ Origin onset } \\
\hline community-acquired & 0 & $2(9.0)$ & $0.139(0.006-3.051)$ & 0.181 \\
\hline nosocomial & $29(100.0)$ & $20.0(91.0)$ & & \\
\hline Prior hospitalization antimicrobial therapy & $14(48.3)$ & $12.0(54.5)$ & $0.777(0.255-2.364)$ & 0.657 \\
\hline no & 2 & 4 & $0.333(0.055-2.016)$ & 0.389 \\
\hline yes & 27 & 18 & & \\
\hline$\geq 2$ & 19 & 9 & $2.744(0.874-8.618)$ & 0.080 \\
\hline Comorbidity & $27(93.1)$ & $18(81.8)$ & $3.000(0.496-18.14)$ & 0.382 \\
\hline diabetes & $4(14.8)$ & $3(16.6)$ & $1.013(0.202-5.079)$ & 1.000 \\
\hline cardiopathy & $9(31.0)$ & $3(16.6)$ & $2.850(0.668-12.15)$ & 0.192 \\
\hline pulmonary disease & $3(11.1)$ & $2(11.1)$ & $1.154(0.175-7.579)$ & 1.000 \\
\hline nefropathy & $2(7.4)$ & $1(5.5)$ & $1.556(0.131-18.35)$ & 1.000 \\
\hline malignancy & $3(11.1)$ & $5(27.7)$ & $0.392(0.082-1.861)$ & 0.267 \\
\hline others & $6(22.2)$ & $4(22.2)$ & $1.174(0.287-4.798)$ & 1.000 \\
\hline Surgery & $16(55.2)$ & $14(63.6)$ & $0.703(0.225-2.191)$ & 0.543 \\
\hline Presence of central venous catheter unit & $22(75.9)$ & $10(45.5)$ & $3.771(1.141-12.46)$ & 0.026 \\
\hline ITU & $1(3.5)$ & $1(4.5)$ & $0.750(0.044-12.70)$ & 1.000 \\
\hline surgical & $5(17.3)$ & $4(18.2)$ & $0.720(0.158-3.269)$ & 0.712 \\
\hline clinical & $10(34.5)$ & $5(22.7)$ & $1.789(0.508-6.293)$ & 0.361 \\
\hline pediatrics & $1(13.5)$ & $2(9.0)$ & $0.357(0.030-4.217)$ & 0.571 \\
\hline others & $12(41.4)$ & $10(45.4)$ & $0.847(0.276-2.592)$ & 0.771 \\
\hline \multicolumn{5}{|l|}{ Source } \\
\hline primary & $21(72.4)$ & $19(86.4)$ & $0.357(0.030-4.217)$ & 0.571 \\
\hline secondary & $8(27.6)$ & $3(13.6)$ & $2.413(0.557-10.44)$ & 0.311 \\
\hline \multicolumn{5}{|l|}{ Length of hospital stay prior to bacteraemia } \\
\hline$>7$ days & $23(79.3)$ & $12(54.5)$ & $3.194(0.933-10.93)$ & 0.059 \\
\hline$<7$ days & $6(20.7)$ & $10(45.5)$ & $0.313(0.091-0.575)$ & 0.059 \\
\hline \multicolumn{5}{|l|}{ Initial antimicrobial therapy } \\
\hline inadequate & $10(34.5)$ & $7(31.8)$ & $1.128(0.346-3.670)$ & 0.841 \\
\hline adequate & $19(65.5)$ & $15(68.2)$ & $0.886(0.272-2.885)$ & 0.845 \\
\hline
\end{tabular}

MRSA: methicillin-resistant Staphylococcus aureus; MSSA: methicillin-susceptible Staphylococcus aureus; BSI: blood stream infection; CI: confidence interval; LOS: length of hospital stay; ITU: intensive-therapy unit. 
TABLE 2 - Potential prognostic death factors associated with Staphylococcus aureus bacteraemia.

\begin{tabular}{|c|c|c|c|c|c|c|}
\hline \multirow[b]{3}{*}{ Factors associated } & \multicolumn{4}{|c|}{ Outcome n $=51$} & \multirow[b]{3}{*}{ Odds ratio $(\mathrm{CI})$} & \multirow[b]{3}{*}{$\mathbf{p}(\leq \mathbf{0 . 0 5})$} \\
\hline & \multicolumn{2}{|c|}{ death $n=24(47.0)$} & \multicolumn{2}{|c|}{ survival $n=27(53.0)$} & & \\
\hline & $\mathbf{n}$ & $\%$ & $\mathbf{n}$ & $\%$ & & \\
\hline \multicolumn{7}{|l|}{ Sex } \\
\hline female & 11 & 45.8 & 9 & 33.3 & $1.692(0.544-5.259)$ & 0.361 \\
\hline male & 13 & 54.2 & 18 & 63.0 & & \\
\hline \multicolumn{7}{|l|}{ Age (years) } \\
\hline$\geq 60$ & 13 & 54.2 & 8 & 29.6 & $2.807(0.88-8.88)$ & 0.075 \\
\hline$\leq 60$ & 11 & 45.8 & 19 & 70.4 & & \\
\hline \multicolumn{7}{|l|}{ Origin onset } \\
\hline community-acquired & 0 & 0.0 & 2 & 7.4 & $0.208(0.009-4.56)$ & 0.491 \\
\hline nosocomial & 24 & 100.0 & 25 & 92.6 & & \\
\hline \multicolumn{7}{|l|}{ Susceptibility to meticillin } \\
\hline resistant & 17 & 70.8 & 12 & 44.4 & $3.035(0.949-9.709)$ & 0.057 \\
\hline sensitive & 7 & 29.2 & 15 & 55.6 & $0.3294(0.1030-1.0533)$ & 0.109 \\
\hline \multicolumn{7}{|l|}{ Antimicrobial therapy } \\
\hline no & 2 & 8.3 & 3 & 11.0 & & \\
\hline yes & 22 & 91.7 & 24 & 89.0 & & \\
\hline$\geq 2$ & 16 & 72.7 & 10 & 41.6 & $2.744(0.874-8.618)$ & 0.034 \\
\hline \multicolumn{7}{|l|}{ Initial antimicrobial therapy } \\
\hline inadequate & 10 & 41.6 & 7 & 25.9 & $2.041(0.625-6.663)$ & 0.234 \\
\hline adequate & 14 & 58.4 & 20 & 74.1 & $0.490(0.150-1.600)$ & 0.234 \\
\hline Comorbidity & 22 & 91.6 & 20 & 74.1 & $3.85(0.714-20.75)$ & 0.146 \\
\hline diabetes & 4 & 18.2 & 3 & 15.0 & $1.60(0.319-8.01)$ & 0.693 \\
\hline cardiopathy & 5 & 22.7 & 4 & 20.0 & $1.51(0.355-6.443)$ & 0.718 \\
\hline pulmonary disease & 3 & 13.7 & 0 & 0.0 & $8.95(0.438-183.0)$ & 0.097 \\
\hline nefropathy & 0 & 0.0 & 4 & 20.0 & $0.106(0.005-2.092)$ & 0.112 \\
\hline malignancy & 5 & 22.7 & 3 & 15.0 & $2.105(0.445-9.950)$ & 0.450 \\
\hline others & 5 & 22.7 & 6 & 30.0 & $0.921(0.241-3.516)$ & 1.000 \\
\hline Surgery & 15 & 62.5 & 15 & 55.5 & $0.777(0.229-2.635)$ & 0.686 \\
\hline Presence of central venous catheter unit & 16 & 66.6 & 16 & 59.3 & $1.375(0.437-4.319)$ & 0.585 \\
\hline ITU & 1 & 4.0 & 1 & 3.7 & $1.130(0.066-19.13)$ & 1.000 \\
\hline surgical & 5 & 20.8 & 4 & 14.8 & $1.513(0.355-6.443)$ & 0.718 \\
\hline clinical & 11 & 45.8 & 5 & 18.5 & $3.457(0.988-12.09)$ & 0.046 \\
\hline pediatrics & 2 & 8.6 & 4 & 14.8 & $0.522(0.086-3.149)$ & 0.671 \\
\hline others & 5 & 20.8 & 13 & 48.2 & $0.283(0.081-0.980)$ & 0.041 \\
\hline \multicolumn{7}{|l|}{ Length of hospital stay prior to bacteraemia } \\
\hline$>7$ days & 21 & 87.5 & 14 & 51.8 & $6.500(1.561-27.06)$ & 0.006 \\
\hline$<7$ days & 3 & 12.5 & 13 & 48.2 & $0.153(0.036-0.640)$ & 0.007 \\
\hline
\end{tabular}

The overall mortality rate was $47 \%$. Univariate analysis for potential prognostic death factors associated with $S$. aureus bacteraemia is presented in Table 2. The presence of MRSA $(\mathrm{p}=0.057)$, clinical status, represented by patient's unit $(\mathrm{p}=0.046)$, and length of hospital stay prior to bacteraemia higher than seven days ( $\mathrm{p}=0.006)$ were significantly associated with death. No difference was found regarding sex, age, severity of underlying disease, nosocomial origin of the infection, or presence of intravascular device among the patients who died compared with the patients who survived.

In multivariate analysis (Table 3), the use of more than two antibiotics was independently associated with mortality by $S$. aureus $(\mathrm{OR}=8.65 ; 95 \% \mathrm{CI}=1.92$ to $39.07 ; \mathrm{p}=0.05)$. ORs observed for long duration of hospital stay $(\mathrm{OR}=4.7)$ and cardiopathy $(\mathrm{OR}=5.85)$ were both high in death patients group.

TABLE 3 - Multivariate analysis for mortality by Staphylococcus aureus bacteraemia.

\begin{tabular}{lccc}
\hline Variable & Odds ratio & $\mathbf{9 5 \%} \mathbf{C I}$ & $\mathbf{p}$ \\
\hline More than two antimicrobial agents & 8.655 & 1.92 to 39.07 & 0.005 \\
\hline MRSA infection & 0.500 & 0.11 to 2.24 & 0.361 \\
\hline Cardiopathy & 5.851 & 0.91 to 37.51 & 0.062 \\
\hline $\begin{array}{l}\text { Presence of intravascular device } \\
\text { Length of hospital stay prior to bacteraemia } \\
>7 \text { days }\end{array}$ & 0.888 & 0.20 to 3.98 & 0.876 \\
\hline
\end{tabular}

CI: confidence interval; MRSA: methicillin-resistant Staphylococcus aureus. 


\section{DISCUSSION}

Hospital-acquired bloodstream infections caused by S. aureus, mainly those due to methicillin-resistant $S$. aureus (MRSA), are associated with significant mortality and morbidity ${ }^{15}$, adding considerable costs to hospital care ${ }^{16}$. In Brazil, S. aureus was the most common cause of bloodstream infection $(20.2 \%)$, and resistance to methicillin was observed in $31 \%$ of S. aureus isolates in the Brazilian hospital participating in the SENTRY Antimicrobial Surveillance Programme ${ }^{9}$. However, MRSA rates may vary greatly among hospitals $(55.9-73 \%)^{8,13}$. In our hospital, bacteraemia rates caused by MRSA were both high in both critical $(63.7 \%)$ and non-critical units $(62.5 \%)^{11}$. In our study, we observed a similar rate $(56.8 \%)$ of BSI due to MRSA in clinical, burned, and oncology wards, and almost all BSIs (96\%) had nosocomial origin.

The emergence of MRSA is largely due to the dissemination of clonal strains between patients favored for poor infection control politics and antimicrobial pressure ${ }^{17}$, but this correlation has been difficult to establish due to the high number of variables involved ${ }^{18}$. Risk factors for methicillin resistance reported in literature also vary among institutions and patients. The major independent risk factors include: advanced age ${ }^{19,20}$, residence in a nursing home $\mathrm{e}^{7,21}$, long duration of hospitalization ${ }^{4}$, prior antibiotic exposure ${ }^{6,22}$, insulin-requiring diabetes ${ }^{23}$, intravascular devices ${ }^{3,24}$, presence of decubitus ulcers or pneumonia as source of $\mathrm{BSI}^{6,15,24}$, inadequacy of antimicrobial therapy, and severity of clinical status ${ }^{13}$.

In the present study, based on univariate analysis, age and presence of central venous catheter (CVC) were risk factors for MRSA bacteraemia as also reported previously ${ }^{10,13}$. Most $(72.4 \%)$ of MRSA bacteraemia were classified as primary, and CVC was probably the foci of infection as discussed by Das et al. ${ }^{24}$. A high proportion of these infections were detected in clinical ward (34.5\%), while most studies reported higher MRSA infections in critical-care units ${ }^{24,25}$.

Other analyzed variables such as length of hospital stay prior to bacteraemia $(\mathrm{OR}=3.19)$, cardiopathy as comorbidity $(\mathrm{OR}=2.85)$, and more than two antimicrobial drugs usage $(\mathrm{OR}=2.74)$, despite having no significance, presented high OR values when compared with MRSA and MSSA infections. Several studies also have demonstrated that longer hospitalization before the onset of bacteraemia ${ }^{25}$ and antimicrobial use in greater frequency ${ }^{10}$ were risk factors for MRSA infection. None of these factors - age, central vascular catheter presence or even the use of more than two antimicrobial drugs, cardiopathy, or longer hospital stay prior to bacteraemia - were independently prognostic factors for MRSA infection in our study.

Comparisons of mortality between patients with MRSA and MSSA have been contradictory in the literature ${ }^{15}$. Several studies including a meta-analysis have demonstrated an increase in mortality among patients with MRSA bacteraemia versus MSSA bacteraemia ${ }^{3,4,26,27}$. In this study, a higher crude mortality of $58.6 \%$ vs $24.1 \%(\mathrm{OR}=3.036 ; \mathrm{p}=0.05)$ was observed in the MRSA group than the MSSA group, respectively, a higher rate than those reported in United Kingdom and United States hospitals ${ }^{15,27}$.

Traditional risk factors for mortality include older age $\mathrm{e}^{10,15,28}$, inadequate treatment ${ }^{13,29}$, and severity of comorbidity ${ }^{25}$. Despite the fact that these variables were not significant in our study, we attribute an association between these risk factors and mortality due to the high OR values of $2.80,2.04$, and 3.85 , respectively. Intensive-care unit admission before bacteraemia is also a predictor for MRSA-BSI mortality ${ }^{15,24}$. Most of the deaths due to staphylococcal BSI occurred in the clinical ward ( $45 \% ; \mathrm{p}=0.046)$, with only $4 \%$ of patients carried out in the ICU.

Length of hospitalization is a measure of morbidity ${ }^{15}$, as well as invasive device use such as $\mathrm{CVC}^{30}$. In the univariate analysis, death was associated with an increase in length of hospital stay for more than seven days $(\mathrm{p}<0.05)$ and the use of more than two antimicrobial drugs $(\mathrm{p}=0.034)$, but only the former was independently significant $(\mathrm{OR}=8.65 ; \mathrm{p}=0.005)$ in multiple regression analysis. In multivariable analysis for the length of hospital stay prior to bacteraemia superior to seven days $(\mathrm{OR}=4.7)$ and cardiopathy as comorbidity $(\mathrm{OR}=5.8)$, we observed high $\mathrm{OR}$ values. These findings coincide with previous reports demonstrating that factors for mortality include: longer of hospital stay before bacteraemia ${ }^{25}$ and comorbidities as cardiopathy ${ }^{31}$. Neverthless, in our study, patients with bacteraemia were usually confined in non-critical units due to lack of sufficient beds in the ICU where $33.3 \%$ of patients received inadequate empirical antimicrobial therapy that resulted in higher rate $(41.6 \%)$ of hospital mortality. Eighty percent of the patients who died using an inadequate treatment were from MRSA BSI group.

One of the limitations of the study was that it was done retrospectively and performed at a single hospital.

In addition, the small sample size of the study limited the detection of statistically significant differences. We also did not use the Apache II or other scores to assess severity of illness prognostic indicator on the hospital mortality.

In conclusion, high hospital mortality was observed even in cases of patients who were admitted in non-critical-care units. We found several risk factors associated to MRSA and MSSA bacteraemia and high mortality level of $S$. aureus bacteraemia. However, the use of two or more antimicrobial agents was the unique independent variable for death. This can be partially justified by high frequency of inadequate empirical therapy observed in our study. In spite of the limitations, mainly the small number of patients, the findings suggest an imperative for hospitals to review their antimicrobial policies.

\section{CONFLICT OF INTEREST}

The authors declare that there is no conflict of interest.

\section{REFERENCES}

1. Grundmann H, Aires-de-Souza MA, Boyce J, Tiemersma E. Emergence and resurgence of methicillin-resistant $S$. aureus as public-health threat. Lancet 2006; 368:874-885.

2. Kopp BJ, Nix DE, Armstrong EP. Clinical and economic analysis of methicillinresistant and methicillin-susceptible $S$. aureus infections. Ann Pharmacother 2004; 38:1377-2382.

3. Cosgrove S, Sakoulas G, Perencevich R, Schwaber MJ, Karchmer AW, Careli Y. Comparison of mortality associated with methicillin-resistant and methicillinsusceptible S. aureus bacteraemia: a meta-analysis. Clin Infect Dis 2003; 36:53-59.

4. Whitby M, McLaws ML, Berry G. Risk of death from methicillinresistant Staphylococcus aureus bacteraemia: a meta analysis. Med J Aust 2001; 175:264-267.

5. Thompson DS, Workman R, Strutt M. Contribution of acquired meticillinresistant Staphylococcus aureus bacteraemia to overall mortality in a general intensive care unit. J Hosp Infect 2008; 70:223-227. 
6. Lodise Jr TP, McKinnon PS, Rybak M. Prediction model to identify patients with $S$. aureus bacteremia at risk for methicillin resistance. Infect Control Hosp Epidemiol 2003; 24:655-661.

7. McHugh CG, Riley LW. Risk factors and costs associated with methicillinresistant $S$. aureus blood-stream infections. Infect control Hosp Epidemiol 2004; 25:425-430

8. Sader H, Jones RN, Gales AC, Silva JB, Pignatari AC. SENTRY participants. SENTRY Antimicrobial Surveillance Program Report: Latin America and Brazilian results for 1997 through 2001. Braz J Infect Dis 2004; 8:25-79.

9. Gales AC, Sader HS, Ribeiro J, Zoccoli C, Barth A, Pignatari C. Antimicrobial susceptibility of Gram-Positive bacteria isolated in brazilian hospitals participating in the SENTRY program (2005-2008). The Braz J Infect Dis 2009; 13:90-98.

10. Ribas RM, Freitas C, Gontijo-Filho PP. Nosocomial methicillin-resistant Staphylococcus aureus bacteremia in a tertiary care hospital: Risk factors, overall mortality and antimicrobial resistance. Int J Med Medical Sci 2009; 1:412-417.

11. Carvalho RH, Gontijo-Filho PP. Epidemiologically relevant antimicrobial resistant phenotypes in pathogens isolated from critically ill patients in a Brazilian universitary hospital. Braz J Microbiol 2008; 39:623-630.

12. Garner JS, Jarvis WR, Emori TG, Horan TC, Hughes JM. CDC definitions for nosocomial infections. Am J Infect Control 1988; 16:128-140.

13. Guilarde AO, Turchi MD, Martelli CMT, Primo MGB. Staphylococcus aureus bacteraemia: incidence, risk factors and predictors for death in a Brazilian teaching hospital. J Hosp Infect 2006; 63:330-336.

14. Ibrahim EH, Sherman G, Ward S, Fraser VJ, Kollef MH. The influence of inadequate antimicrobial antimicrobial treatment of bloodstream infections on patient outcomes in the ICU setting. Chest 2000; 118:146-155.

15. Cosgrove SE, Qi Y, Kaye KS, Harbarth S, Karchmer AW, Carmeli Y. The impact of methicillin-resistance in Staphylococcus aureus bacteremia on patient outcomes: mortality, length of stay, and hospital charges. Infect Control Hosp Epidemiol $2005 ; 26: 166-174$.

16. Millar BC, Loughrey A, Elborn JS, Moore JE. Proposed definitions of communityassociated meticillin-resistant Staphylococcus aureus (CA-MRSA). J Hosp Infect 2007; 67:109-113

17. Da Silva Coimbra MV, Silva-Carvalho MC, Wisplinghoff H, Hall GO, Tallent S, Wallace S, et al. Clonal spread of methicillin-resistant Staphylococcus aureus in a large geographic area of the United States. J Hosp Infect 2003; 53:103-110.

18. Tenover FC, Moellering Jr RC. The rationale for revising the Clinical and Laboratory Standards Institute vancomycin minimal inhibitory concentration interpretative criteria for Staphylococcus aureus. Clin Infect Dis 2007; 44:12081215

19. Cordova SP, Heath CH, McGechie DB, Keil AD, Beers MY, Riley TV. Methicillin resistant Staphylococcus aureus bacteraemia in Western Australia teaching hospitals, 1997-1999: risk factors, outcomes and implications for management. J Hosp Infect 2004; 56:22-28

20. Davis KA, Stewart JJ, Crouch HK, Florez CE, Hospenthal DR. Methicillinresistant Staphylococcus aureus (MRSA) nares colonization at hospital admission and its effect on subsequent MRSA infection. Clin Infect Dis 2004; 39:776-782.

21. Jernigan J, Pullen A, Flowers L, Bell M, Jarvis W. Prevalence of and risk factors for colonization with meticillin-resistant Staphylococcus aureus at the time of hospital admission. Infect Control Hosp Epidemiol 2003; 24:409-414.

22. Pujol M, Pena C, Pallares R, Ayats J, Ariza J, Gudiol F. Risk factors for nosocomial bacteraemia due to methicillin-resistant Staphylococcus aureus. Eur J Clin Microbiol Infect Dis 1994; 13:96-102.

23. Boyko EJ, Ahroni JH, Stensel V, Forsberg RC, Davignon DR, Smith DG. A prospective study of risk factors for diabetic foot ulcer. Diabetes Care 1999; 22:1036-1042.

24. Das I, O'Connell N, Lambert P. Epidemiology, clinical and laboratory characteristics of Staphylococcus aureus bacteraemia in a university hospital in UK. J Hosp Infect 2007; 65:117-123.

25. Wang FD, Chen YY, Chen TL, Liu CY. Risk factors and mortality in patients with nosocomial Staphylococcus aureus bacteremia. J Infect Control 2008; 36:118-122.

26. De Oliveira Conterno L, Wey SB, Castelo A. Staphylococcus aureus bacteraemia: comparison of two periods and a predictive model of mortality. Braz J Infect Dis 2002; 6:288-297.
27. Melzer M, Eykyn SJ, Gransden WR, Chinn S. Is methicillin-resistant Staphylococcus aureus more virulent than methicillin-susceptible $S$. aureus? A comparative cohort study of British patients with nosocomial infection and bacteraemia. Clin Infect Dis 2003; 37:1453-1460.

28. Nickerson EK, Wuthiekanun V, Wongsuvan G, Limmathurosakul D, Srisamang P, Mahavanakul W, et al. Factors Predicting and Reducing Mortality in Patients with Invasive Staphylococcus aureus Disease in a Developing Country. Plos One 2009; 4:1-8

29. Libert M, Elkholti M, Massaut J, Karmali R, Mascart G, Cherifi S. Risk factors for meticillin resistance and outcome of Staphylococcus aureus bloodstream infection in a Belgian university hospital. J Hosp Infect 2008; 68:17-24.

30. Vincent JL. Nosocomial infections in adult intensive-care units. Lancet 2003; 361:2068-2077.

31. Soriano A, Martinez JA, Mensa J, Marco F, Almela M, Moreno-Martinez A, et al Pathogenic significance of methicillin resistance for patients with Staphylococcus aureus bacteraemia. Clin Infect Dis 2000; 30:368-373. 